\title{
SPEAKING FOR THEMSELVES? UNDERSTANDING African Freed Slave Testimonies from the WESTERN INDIAN OCEAN, 1850s-1930s
}

\author{
Edward A. Alpers \\ Matthew S. Hopper
}

To cite this article: Alpers, A. Edward and Matthew S. Hopper. "Speaking for Themselves? Understanding African Freed Slave Testimonies from the Western Indian Ocean, 1850s-1930s." Journal of Indian Ocean World Studies, 1 (2017), pp. 6088 .

More information about the Journal of Indian Ocean World Studies can be found at: jiows.mcgill.ca

(C) Edward A. Alpers and Matthew S. Hopper. This is an Open Access article distributed under the terms of the Creative Commons License CC BY NC SA, which permits users to share, use, and remix the material provide they give proper attribution, the use is non-commercial, and any remixes/transformations of the work are shared under the same license as the original. 


\title{
SPEAKING FOR Themselves? UNDERSTANDING African Freed Slave Testimonies from the WESTERN INDIAN OCEAN, 1850S-1930S*
}

\author{
Edward A. Alpers \\ UCLA
}

\author{
Matthew S. Hopper \\ Cal Poly, San Luis Obispo
}

\begin{abstract}
In this article we mine an array of British anti-slavery materials seeking the voices of enslaved East Africans in the western Indian Ocean. We draw attention to the numerous problems of translation involved in this kind of basic research and to the critical role played by both indigenous and British interpreters in the process of enabling captive Africans to "speak for themselves." The lesson here is that historians must exercise particular care in utilizing these precious sources.
\end{abstract}

\section{INTRODUCTION}

At the very end of 1878, W.H. Hathorne, the United States Consul at Zanzibar, wrote to his British counterpart, John Kirk, concerning the seizure by officers of HMS London of three enslaved Africans from the American bark, "Lacouia," of New Bedford, Massachusetts. ${ }^{1}$ At issue was the alleged testimony of the Africans in question, whom the British naval officers charged had been forcibly seized the previous July by the Americans on the beach at the island of Nzwani (Johanna), whereas Consul Hathorne asserted that they were given to the ship by their "master," Dr. Wilson, a sugar planter at Nzwani. ${ }^{2}$

\footnotetext{
* Edward A. Alpers et Matthew S. Hopper, « Parler en son nom ? Comprendre les témoignages d'esclaves africains originaires de l’océan Indien (1850-1930) », Annales HSS, 63-4, 2008, p. 799-828, () Ehess, Paris. Reproduced with permission.

1. An earlier version of this paper was presented at the annual meeting of the American Historical Association in Washington, DC, in January 2008. The authors wish to thank Sondra Greene for suggestions she made as discussant for the paper, as well as the members of the research seminar in African History at UCLA and the anonymous readers of Annales for their valuable comments on that draft.

2. Dr. Benjamin Wilson was surgeon on board a whaler from New Bedford, Massachusetts, who in 1872 settled on Nzwani with a 30-year lease of 2,000 hectares from Sultan Abdallah III on the Patsi plains near the capital of Mutsamudu. Six years later, the Sultan ordered the inhabitants of three Patsi villages
} 
According to Hathorne, the dispute hinged on translation of what the Africans, "who are 'Wa-Makua' and not 'Waswaheli," were reported to have said to the British seamen.

Interpreters in Swaheli language being so entirely different from those taken before one, I can only attribute to the fact that the negroes could understand but a very little of the Kiswaheli language and such being the case, not very much weight can be attributed to the interpretation of their statements as rendered by Lieutenants O’Neill and Cutfield. ${ }^{3}$

Hathorne ultimately was "obliged to employ a 'Makuwa' interpreter to understand them thoroughly," and when he did, he learned not only the circumstances of their capture, but also who they were. ${ }^{4}$ During the interrogation by Hawthorne and Captain Rufus W. Gifford of the British vessel, they learned that the three men were named Similla, M'cassa, and Fereggie. When the Consul asked, "Can you speak Kiswahili?" Similla replied, "I understand very little in this language as it is not my own; I do thoroughly understand Anzwani or Johanna and Makuwa languages."

This incident highlights a basic problem with many personal testimonies by Africans from the era of the slave trade in eastern Africa and raises a number of important questions about all such documents. The key issue is that while scholars of Indian Ocean slavery have identified an increasing number of examples of African voices among the enslaved, virtually all of them are mediated in one way or another by translation. Nevertheless, these important sources, which range from the briefest of testimonies to fairly lengthy narratives, are unique in being the only sources available that put a face on the individual human beings who were caught up by the vicious whirlwind of the slave trade in nineteenth-century eastern Africa. They also enable us to arrive at some broad generalizations about the experiences of these individuals once they were swept up in

off their land so that Wilson could develop his plantation unimpeded by village cultivation. Jean Martin, Comores: quatre îles entre pirates et planteurs, vol, 2 (Paris: L'Harmattan, 1983), 10-12; Pierre Vérin, Les Comores (Paris: Éditions Karthala, 1994), 104-105; Gary W. Clendennen and Peter M. Nottingham, William Sunley and David Livingstone: A Tale of Two Consuls (African Studies Program, University of Wisconsin-Madison, 2000), 71.

3. W.H. Hathorne to John Kirk, Zanzibar, 31 December 1878, Zanzibar National Archives (hereafter ZNA), AA $1 / 23$.

4. Ibid.

5. Sworn statement of “Three negroes unlawfully taken," signed by Hathorne, 28 December 1878, ZNA, AA 1/23. According to a statement given to Cutfield aboard the HMS London on 24 December 1878, their names are given as M'passi, Similli, and Mladi: ZNA, AA1/24. Although Swahili and Nzwani are both included in the same Bantu G.40 Group, they are not mutually intelligible, while Makua is classified as the very different Bantu P.30 set of languages. See Raymond G. Gordon, Jr. (ed.), Ethnologue: Languages of the World, Fifteenth edition (Dallas, Tex.: SIL International, 2005). Online version: http:// www.ethnologue.com/. Accessed on 1 March 2008. 
that terrible commerce. In this paper we present a representative sample of such sources from eastern Africa with a focus on the ways in which African voices came to appear in the historical record at a time and under circumstances in which they could not actually speak for themselves.

The question of whether the enslaved or subaltern may actually speak for themselves was raised provocatively by Gayatri Spivak and has been revisited variously ever since. Spivak's interrogation of the representation (and 're-presentation') of the subaltern subject in theoretical and historical texts has presented a challenge to social historians of imperialism and slavery that endures until today. Her determination that the "subaltern as female cannot be heard or read" is exemplified poignantly by descriptions of colonial and post-colonial forces claiming to represent the silent dead. Whether Victorian imperialist justifying a civilizing mission in India through the mistranscribed names of widows of sati, male independence movement leaders interpreting Bhuvaneswari Bhaduri's suicide, or the contemporary historian/critic attempting to represent the motives/actions of masses/workers/subaltern, she concludes that "one cannot put together a 'voice"'"6

Recently, Eve Troutt Powell reiterated Spivak's challenge for scholars attempting to find a voice of enslaved Africans in the historiography of the Middle East. ${ }^{7}$ Likewise, Ehud Toledano, in examining the history of enslaved populations in the Ottoman Empire, has concluded that in the absence of a significant number of slave narratives - "which increased the difficulty in reconstructing the voices of the enslaved" - the research requires that one "adopt a more flexible approach to the interpretation of the available sources." Toledano suggests using techniques of "voice recovery" or "experience reconstruction," processes which expand the definition of "voice" from speech alone to action-as both commission and omission-relying on careful examination of silences and the use of at least some measure of imagination, which he employs with varying degrees of success to complex documentary material. ${ }^{8}$

Unlike Toledano and his investigation of the Ottoman case, we cannot complain of the same "paucity of first-person accounts" of enslaved Africans in the Western Indian

6. Gayatri Chakravorty Spivak, "Can the Subaltern Speak?” reprinted in Patrick Williams and Laura Chrisman (eds.), Colonial Discourse and Post-Colonial Theory: A Reader (New York: Columbia University Press, 1994), 66-111. See also: Abena P. A. Busia, "Silencing Sycorax: On African Colonial Discourse and the Unvoiced Female," Cultural Critique 14 (Winter 1989-1990): 81-104; Gyan Prakash, "Writing Post-Orientalist Histories of the Third World: Perspectives from Indian Historiography," Comparative Studies in Society and History 32, no. 2 (1990): 383-408; "Subaltern Studies as Postcolonial Criticism, American Historical Review 99, no. 5 (1994): 1475-1490.

7. Eve M. Troutt Powell, "Will That Subaltern Ever Speak? Finding African Slaves in the Historiography of the Middle East," in Israel Gershoni, Amy Singer and Y. Hakan Erdem (eds.), Middle East Historiographies: Narrating the Twentieth Century (Seattle: University of Washington Press, 2006).

8. Ehud Toledano, As If Silent and Absent: Bonds of Enslavement in the Islamic Middle East (New Haven: Yale University Press, 2007), 34-35. 
Ocean. We have identified numerous examples of enslaved Africans "speaking" - or at least attempting to convey first-person narratives - to a variety of European officials in various capacities around the Indian Ocean. These narratives, however, suffer from many of the same "layers of mediation" identified by Kathryn Joy McKnight and reiterated by Toledano. ${ }^{9}$ These accounts are complicated by problems of transcription, translation, and representation, but are nevertheless of immense value.

To understand these accounts better, it is useful to consider them in comparison to several representative accounts by former enslaved Africans in the Atlantic world. The earliest Atlantic account dates to 1770. Written by James Albert Ukawsaw Gronniosaw, it tells of his upbringing in Bornu (now in northeastern Nigeria), his enslavement, his experiences of slavery and freedom, and his redemption in England. ${ }^{10}$ Not quite 50 pages in length, it was reprinted a number of times on both sides of the Atlantic during the late eighteenth and early nineteenth centuries. In 1787, Ottobah Cugoano, later known as John Stuart, published his Thoughts and Sentiments on the Evil and Wicked Traffic of the Commerce of the Human Species as the first African literary contribution to the British antislave trade movement. Noteworthy for its condemnation not only of the slave trade, but of the institution of slavery, it includes an account of his capture that runs to about seven pages. ${ }^{11}$ The best known of the Atlantic accounts, however, is unquestionably Olaudah Equiano's Interesting Narrative, which stands as one of the most important documents of the British movement to abolish the slave trade. ${ }^{12}$ First published in 1789, Equiano's lengthy autobiography went through nine editions by 1794 and was certainly the most well known work by an African in the late eighteenth century. Widely traveled and literate in English, as well as an accomplished propagandist, Equiano (who always identified himself as Gustavus Vassa) gave voice to the African experience of enslavement and slavery itself, as well as to his own peregrination from freedom to slavery and back to freedom by purchase. However much he may have been influenced by the abolitionist sentiments of others, there is no doubting that Equiano's words were his own. ${ }^{13} \mathrm{~A}$ third example of this

9. Kathryn Joy McKnight, “En su tierra lo aprendió': An African Curandero's Defense before the Cartagena Inquisition," Colonial Latin American Review 12, no. 1 (2003): 63-85, quoted in Toledano, As If Silent and Absent (2007), 34.

10. James Albert Ukawsaw Gronniosaw, A Narrative of the Most Remarkable Particulars in the Life of... an African Prince (Bath: W. Gye, 1770).

11. Ottobah Cugoano, Thoughts and Sentiments on the Evil and Wicked Traffic of the Commerce of the Human Species (London: n.p., 1787); for an electronic edition of Cugoano's enslavement only, see "Narrative of the Enslavement of Ottabah Cugoano, a Native of Africa; published by himself, in the Year 1787," electronic edition, University of North Carolina-Chapel Hill, 1999: http:/docsouth.unc.edu/neh/ cugoano.html.

12. Olaudah Equiano, The Interesting Narrative and Other Writings, ed. Vincent Carretta (New York: Penguin Books, 1995).

13. For the lively debate over whether or not Equiano was indeed born in Africa, see Vincent Carreta, 
kind of extended narrative is the biography of Mahommah Gardoo Baquaqua, who was enslaved to Brazil, escaped from slavery in New York, and fled to Haiti before returning to the United States and Canada. ${ }^{14}$ Published in 1854, while Baquaqua's narrative apparently involved several hands, Robin Law and Paul Lovejoy argue persuasively that it is primarily autobiographical. This short book or lengthy pamphlet of 66 pages is remarkable for its lengthy description of life in that part of the West African hinterland where Baquaqua grew up (in the modern northern Republic of Benin), as well as for the personal narrative of the author himself. Although their histories may be somewhat different, all four of these publications embody the strong influence of Christianity on the lives of their authors and all were self consciously created in the context of abolition.

Unlike the better known and more extensive accounts from the Atlantic slave trade, those from Africans whose enslavement drew them into the Indian Ocean trade are for the most part quite brief and were not generated by the enslaved themselves. With one exception, the kinds of sources we analyze here derive from official British records pertaining to the abolition of slavery and the slave trade in the Western Indian Ocean. The first of these consists of Admiralty records from Indian Ocean antislavery efforts; the second includes various types of consular records from East Africa; and the third is represented by consular records from Arabia. ${ }^{15}$ Each of these varieties of sources yields

Equiano, the African: biography of a self-made man (Athens: University of Georgia Press, 2005) and "Response to Paul Lovejoy's 'Autobiography and Memory: Gustavus Vassa, alias Olaudah Equiano, the African'," Slavery \& Abolition, 28, 1 (2007): 115-119; Paul Lovejoy, "Autobiography and Memory: Gustavus Vassa, alias Olaudah Equiano, the African," Slavery \& Abolition, 27, no, 3 (2006): 317-347 and "Issues of Motivation - Vassa/Equiano and Carretta's Critique of the Evidence," Slavery \& Abolition, 28, no. 1 (2007): 121-125.

14. Robin Law and Paul E. Lovejoy (eds.), The Biography of Mahommah Gardo Baquaqua: His Passage from Slavery to Freedom in Africa and America (Princeton: Markus Wiener, 2001).

15. In this paper, we do not include the narratives of freed slaves who populated the first generation of Christian converts as a consequence of the practice of the British authorities presenting them to both British and French missionary societies established at Zanzibar in the second half of the nineteenth century. See, e.g., Kirk to Derby, 14 September 1877, enclosing report by Père Anton Horner, Bagamoyo, 25 June 1877, of the number of freed slaves given by the Sultan of Zanzibar to the French Catholic Mission at Bagamoyo, 1873-1 June 1977 [total 166 of which 75 were male, 91 female; 104 children \{68 male and 36 female $\}$ and 62 adults $\{7$ male and 55 female\}], ZNA, AA1/20. Ibid., "Statement of Freed Slaves received by the Church Missionary Society Mombasa East Coast of Africa," loose insert signed Russell, September 1875-March 1877, accounting for 116 men, 86 women, 110 boys, 55 girls. Ibid., another chart reporting the disposition of 270 freed slaves in 1877 to the CMS, UMCA, the French, and to the Cape. "Relation of slave vessels \& slaves captured by British cruisers \& condemned in the Admiralty Court of Zanzibar for the year 1874-1878 and showing the disposition of the slaves," giving a total of 2127, with 596 sent to Natal, 973 to Zanzibar Missions, and 558 "Freed in Zanzibar," ZNA, AA1/23. The missionary sources are reasonably well represented in the scholarly literature. See, e.g., Edward A. Alpers, "The Story of Swema: Female Vulnerability in Nineteenth-Century East Africa," in Claire G. Robertson \& Martin A. Klein (eds.), Women and Slavery in Africa (Madison: University of Wisconsin Press 1983), 
valuable information about slavery in the Indian Ocean, but each also presents its own set of problems. Whatever the specific source, some potential variables that may affect the ability of an African witness to speak directly to us are the age of the individual, the length of time from that person's initial captivity or sale into slavery and the moment at which her testimony was recorded, the degree of directedness of the questions that yielded a particular testimony, and the historical context in which the testimony was recorded.

\section{The SLAVE TRADE IN EASTERn Africa AND THE WESTERN INDIAN OCEAN}

The slave trade in eastern Africa and the western Indian Ocean reached its zenith in the nineteenth century, and suppression of the slave trade provided one of the primary justifications for European colonial occupation of eastern Africa. Deeply influenced by the rhetoric of abolitionism, the historiography of the slave trade in the region was long inclined to characterize the trade as being both ancient and exclusively Oriental, a perspective which still persists in many popular accounts. In fact, there is little evidence that the slave trade was economically significant in the overall pattern of international trade linking eastern Africa to the Indian Ocean until the late seventeenth century and that it really only took off around the middle of the eighteenth century. Furthermore, the forces that combined to give rise to the prominence of slave trading in eastern Africa at that time owed almost as much to European as they did to Asian demands for chattel African labor, as well as to African patterns of consumption.

The transition began initially with the consolidation of Pate as the center of a vibrant northern Swahili economy during the sixteenth century connected to southern Arabia and then shifted to Oman in the late seventeenth century, where a land-based, theocratic state changed itself by the mid-eighteenth century to a coastal-based, outward-looking, mercantile state with strong financial linkages through Gujarati merchants to British India and imperial pretensions to control the coast of eastern Africa. In the first instance, the consolidation of power in the Lamu Archipelago gave rise to an increased slave trade from Madagascar to the coast and then from the coast on to southern Arabia. ${ }^{16}$ In the

185-219. The several Universities Mission to Central Africa (UMCA) testimonies are discussed at some length in Alpers, "Representations of Children in the East African Slave Trade," Slavery \& Abolition 30, no. 1 (2009): 27; and “The Other Middle Passage: The African Slave Trade in the Indian Ocean," in Emma Christopher, Cassandra Pybus \& Marcus Rediker (eds.), Many Middle Passages: Forced Migration and the Making of the Modern World (Berkeley/Los Angeles/London: University of California Press, 2007), 20-38. Church Missionary Society autobiographies are carefully analyzed in: Fred Morton, "Small Change: Slave Children and the $19^{\text {th }}$ Century East African Slave Trade," in Gwyn Campbell, Suzanne Miers, and Joseph C. Miller (eds.), Children in Slavery through the Ages (Athens: Ohio University Press, 2009), 55-70.

16. Thomas Vernet, "Les Cités-États Swahili de l’Archipel de Lamu, 1585-1810. Dynamiques Endogènes, 
second phase, the expansion of date plantations in Oman requiring large inputs of slave labor during this period constituted a virtually unprecedented new demand for slaves from eastern Africa. The Busaidi dynasty that came to power in Oman in the 1740s was committed to expanding its authority in eastern Africa and by 1828 had firmly established its hegemony over the coast. When in 1840 the most successful of these merchant-rulers, Sayyid Said ibn Sultan, effectively transferred his court from Muscat to Zanzibar, the basis for creation of a major plantation economy complex in East Africa with a commensurate demand for slave labor on both the offshore islands and the opposite mainland based on cloves, coconuts, and grain was well established. Farther north along the coast, but also within the orbit of the Omani empire in eastern Africa, a parallel demand for labor was created in the region of the Juba and Shabelle rivers for export grain production.

To the south, a similar process occurred with the successful establishment from the 1720 s by the French at the Indian Ocean islands of La Réunion (then Bourbon) and Mauritius (then Île de France) of a Caribbean-model plantation economy based on various crops, but above all on sugar. Although war interrupted the French demand for slave labor at the century's close, it was augmented in the 1780s from Saint-Domingue (Haiti); thereafter, slave trading continued more or less openly at La Réunion after the trade was declared illegal in 1817 and until abolition in $1848 .{ }^{17}$ In 1854 the continuing demand for labor gave rise to a quasi-slave trade in "free" contract laborers (émigrés libres) from Mozambique and Madagascar; smuggling under various guises into Mauritius also continued until slaves were replaced by indentured laborers from South Asia. ${ }^{18}$ In addition, during the first half of the nineteenth century, traders from the booming Brazilian plantation economy were especially active at Mozambique and Quelimane. In

Dynamiques Exogènes," Université Paris I, 2005, 170-192.

17. Alpers, "The French Slave Trade in East Africa (1721-1810)," Cahiers d'Études Africaines, 10, 37 (1970), 80-124; Hubert Gerbeau, "L'Océan Indien n'est pas l'Atlantique. La traite illegae à Bourbon au XIX siècle," Outre-Mers. Revue d'Histoire 89, no. 336-337 (2002): 79-108.

18. For La Réunion, see Sudel Fuma, "La traite des esclaves dans le basin du Sud-Ouest de l'Océan Indien et la France après 1848," in Rakoto Ignace (ed.), La Route des Esclaves: Système servile et traite dans l'est malgache (Paris: L'Harmattan, 2000), 247-261; Yvan Combeau, Prosper Eve, Sudel Fuma, Edmond Mastri, Histoire de La Réunion: De la colonie la région (La Réunion: Université de La Réunion CRESOI \& SEDES, 2001), 77-90; Héloïse Finch, "Comprendre la traite illégale d'esclaves pendant l'occupation Britannique de La Réunion à travers les archives britanniques," in Laurent Médéa, Lucette Labache and Françoise Vergès (eds.), Identité et société réunionnaise: Nouvelles perspectives et nouvelles approches ( $\mathrm{Pa}-$ ris: Éditions Karthala, 2005), 67-88; for Mauritius, see Richard B. Allen, Slaves, Freedmen, and Indentured Laborers in Colonial Mauritius (Cambridge: Cambridge University Press, 1999); H. ly Tio Fane Pinto, Lured Away: The Life History of Indian Cane Workers in Mauritius (Moka: Mahatma Gandhi Institute, 1984); Marina Carter, Lakshmi's Legacy: The Testimonies of Indian Women in $19^{\text {th }}$ Century Mauritius (Rose-Hill, Mauritius: Editions de l'Océan Indien,1994); Saloni Deerpalsingh \& Marina Carter, Select Documents on Indian Immigration: Mauritius, 1834-1926, 3 vols. (Moka: Mahatma Gandhii Institute, 1994-1996. 
fact, $21 \%$ of all enslaved Africans landed at Rio de Janeiro in the second two decades of the nineteenth century were from eastern Africa. ${ }^{19}$ From the late eighteenth century, Madagascar - previously only a source of slaves for export - became yet another market for slave labor, where first the Sakalava rulers of western Madagascar and then the highland Merina empire, which after 1820 sought to achieve autarky, required substantial inputs of servile labor. ${ }^{20}$ Even the Dutch colony at the Cape of Good Hope provided a source of demand during the eighteenth century. ${ }^{21}$

Slave trading and the broader incorporation of eastern Africa into the rapidly evolving world capitalist market during the nineteenth century gave rise to major expansion of the use of slave labor within the region. We have already noted those instances that were more directly associated with the rise of the ruling class of Busaidi Zanzibar, but other instances include the acquisition of agricultural slaves to produce food for passing caravans and both military retainers and slave wives to enhance the personal authority of the new African trading elites who were coming to power in the context of this new, commercially driven political economy. ${ }^{22}$ Since the Zanzibar Sultanate controlled coastal exports north of Portuguese East Africa, it is not surprising that much of the interior slave trade was in the hands of Arab and Swahili slave traders; but not all. Probably the most notorious African slave traders in the region were the Yao, who also specialized in the ivory trade, although certain Makua chiefs were also infamous slavers. ${ }^{23}$ Yet the slave trade was everywhere a business for small-scale entrepreneurs, as well. Individual trading, kidnapping, sale of debt pawns, the distortion of legal judgments so that any

19. Alpers, "Mozambiques' in Brazil: Another Dimension of the African Diaspora in the Atlantic World," in José C. Curto and Renée Souloudre-LaFrance (eds.), Africa and the Americas: Interconnections during the Slave Trade (Lawrenceville, NJ: Africa World Press, 2005), 43-64; Manolo Florentino, "Slave Trade between Mozambique and the Port of Rio de Janeiro, c.1790-1850, Demographic, Social and Economic Aspects," in Benigna Zimba, Edward Alpers, and Allen Isaacman (eds.), Slave Routes and Oral Tradition in Southeastern Africa (Maputo: Filsom Entertainment, 2005), 63-90; Jane Hooper and David Eltis, "The Indian Ocean in Transatlantic Slavery," Slavery \& Abolition 34, no. 3 (2013): 353-375.

20. Gwyn Campbell, An Economic History of Imperial Madagascar, 1750-1895: The Rise and Fall of an Island Empire (Cambridge: Cambridge University Press, 2005), 213-242.

21. Patrick Harries, "Making Mozbiekers: History, Memory and the African Diaspora at the Cape," in Zimba, Alpers and Isaacman (eds.), Slave Routes and Oral Tradition, 94-97.

22. See, i.a., Frederick Cooper, Plantation Slavery on the East Coast of Africa (New Haven and London: Yale University Press, 1977); Abdul Sheriff, Slaves, Spices \& Ivory in Zanzibar: Integration of an East African Commercial Empire into the World Economy, 1770-1873 (London: James Currey, 1987); Jonathon Glassman, Feasts and Riot: Revelry, Rebellion, and Popular Consciousness on the Swahili Coast, 1856-1888 (Portsmouth, NH: Heinemann, 1995), 29-114; Jan-Georg Deutsch, Emancipation without Abolition in German East Africa c. 1884-1914 (Oxford: James Currey/Dar es Salaam: Mkuki na Nyota/Athens: Ohio University Press, 2006), 15-96.

23. Alpers, Ivory and Slaves in East Central Africa (Berkeley \& Los Angeles: University of California Press, 1975). 
guilty party might be sold to a passing caravan or carried to the coast for sale, and selfcommitment to slavery as a last defense against starvation or abandonment all helped to swell the ranks of enslaved people in eastern Africa during the increasingly chaotic nineteenth century.

The dimensions of the slave trade in eastern Africa are particularly difficult to establish because most of the trade lay beyond the view of European observers, who are our usual source of such quantitative data. Not surprisingly, therefore, although there are several attempts to reconstruct figures for different segments of the trade in the nineteenth century, they are at best approximations; no one has attempted anything like a methodical quantitative analysis of the trade as a whole during this period. ${ }^{24}$ Paul Lovejoy suggests a global figure for East African exports of enslaved Africans at 100,000 for the seventeenth century; 400,000 for the eighteenth century; and 1,651,000 for the nineteenth century, half of whom were sent overseas, half of whom were retained on the coast. Including the Red Sea and Madagascar, Pier Larson proposes 310,000 for the seventeenth century; 752,000 for the eighteenth century and 1,312,000 for the nineteenth century. ${ }^{25}$ Finally, when considering numbers, we must again remember that as the century progressed, slavery and the slave trade became increasingly an internal phenomenon in eastern Africa. But however elusive the precise figures, it is certain that during this period, the slave trade in eastern Africa grew to previously unimagined heights, with disastrous consequences for many of the peoples of the region. The African voices that lie at the center of our paper all come from the last half century of this traumatic period.

\section{Admiralty ReCORDS}

Our first category of evidence is British Admiralty records. ${ }^{26}$ Among these are slave

24. Edmond B. Martin and T.C. Ryan, "A quantitative assessment of the Arab slave trade of East Africa," Kenya Historical Review, 5 (1977), 71-91; Ralph A. Austen, "The $19^{\text {th }}$ century Islamic slave trade from East Africa (Swahili and Red Sea coasts): A tentative analysis," Slavery \& Abolition, 9/3 (1988): 21-44; Sheriff, Slaves, Spices \& Ivory, 33-76; Alpers, "Mozambique and 'Mozambiques': Slave Trade and Diaspora on a Global Scale," in Zimba, Alpers and Isaacman (eds.), Slave Routes and Oral Tradition, 47-61. 25. Lovejoy, Transformations in Slavery: A History of Slavery in Africa, Second Edition (Cambridge: Cambridge University Press, 2000), 61-62, 155-158. Cf. Patrick Manning, Slavery and African Life: Occidental, Oriental, and African Slave Trades (Cambridge: Cambridge University Press, 1990), 79-81; Pier Larson, Ocean of Letters: Language and Creolization in an Indian Ocean Diaspora (New York: Cambridge University Press, 2009), 41.

26. A number of published narratives by British officers who served on board vessels of the Anti-Slave Trade Patrol in East African waters in the middle decades of the nineteenth century include dramatic descriptions of African captives whom they freed upon seizure of Arab dhows carrying their cargoes in East African waters, but for the most part these remain British accounts and do not include first-hand accounts by Africans themselves. For a discussion of such accounts, see Alpers, "Representations of 
narratives preserved in the form of testimony associated with the antislavery campaigns of the British Royal Navy. These sources perhaps challenge the notion of narrative in the conventional sense more than any other form. The surviving records reveal that the naval officers charged with recording the narratives of fugitive slaves who swam off to British ships or those of captives seized on the high seas found it difficult to record slave narratives in the first person, perhaps because these were mediated by interpreters who referred to the subjects in the third person. Indeed, these narratives often vacillate between the first and third person, stifling the personal nature of testimonies even more than the questionnaire format of manumission testimonies (discussed below). In June 1887, two runaway slaves from Sur (the main port for the importation of enslaved persons in this period), a man named Yusuf and a woman named Rasiki, walked twelve miles from Sur to Ras Al-Hadd to seek the protection of the HMS Osprey which was then at anchor off the coast of Oman. When they were taken aboard, the captain awkwardly recorded their testimonies. Yusuf's testimony appears in the Admiralty record as follows:

Jusef a slave of Mohammad bin Juma an Arab living at Sur Mkirimitani [probably a neighborhood within Sur] has been his slave for two years, he comes from near Bagamoyo, he arrived at Sur three years ago being brought there by Abdullah to whom he was a slave and who sold him to his present master, he was a free man on the coast of Africa, he was kidnapped by Abdullah at Simboranga [a mouth of the Rufiji River $]^{27}$, put into a Dhow with many others, we left the coast, kept right out to sea, and did not sight any land till we arrived at Ras al Hadd, we were landed at Shehr [Ras Sherh] close to Khor Joramah [Jarama] in the dhow's boats, walked to Sur and were sold there, ${ }^{28}$ we left the coast in June on $1^{\text {st }}$ of Ramasan strong monsoon. I have run away from my master and come for protection because his master took him into a boat fishing, giving him nothing for his work, when he asks for anything his master beats him, he has no marks of ill treatment about him.

Rasiki's statement was recorded equally awkwardly:

A woman named Rasiki slave to Ali bin Juma living at Sur. Have been his slave

Children."

27. Identified in J. Kirk, "Examination of the Lufigi River Delta, East Africa”, Journal of the Royal Geographical Society of London, 18, no. 1 (1873-1874), 74-76, as "the largest and deepest" mouth of the Rufiji River, with accompanying sketch map; and F. Elton, "On the Coast Country of East Africa, South of Zanzibar," Journal of the Royal Geographical Society of London 44 (1874): 231, 233, and accompanying map. 28. Khor Jarama is a large sheltered inlet with an excellent anchorage $31 / 2$ miles west of Ras Al-Hadd and 12 miles east of Sur. See The Red Sea and Gulf of Aden Pilot, $5^{\text {th }}$ edition (London: Eyre and Spottiswoode for the Hydrographic Office, 1900), 475-476. 
since 18 months, have been 18 months in the country was brought from Chooni close to Pangani [on the northeastern coast of mainland Tanzania], belong to the Mgindo [Ngindo, in southeastern mainland Tanzania] tribe, when she was a little girl at Chooni where she lived with her parents she went to the beach to wash clothes a man took her and put her into a dhow and took her to Zanzibar where she lived with her master at Shangani [the mtaa or neighborhood at Ras Shangani, the westernmost promontory of Zanzibar Town] who put her into a dhow at Malindi (an island of Zanzibar) [an mtaa and port at the north of Zanzibar Town] a bedin belonging to Sur in which there were 20 slaves it was the end of the SW monsoon we first anchored at Msena, where I was kept there 2 days then put on a camel and brought to Sur where she was sold. ${ }^{29}$

The following year, the HMS Griffon accepted a fugitive slave off of the coast of the island of Pemba in East Africa and recorded the following testimony from a man named Muhandu:

Age unknown, native of Boonde [Bondei, in northeastern Tanzania], freeman recently employed at the German trading and commercial station in the aforementioned place. About six weeks ago a Swahili trader Ndugumbi employed him to take a letter to an Arab named Houssein at Pangani. After the delivery of the letter he was forcibly detained in the house: three days afterwards he with nine other slaves were put in a boat by night and taken to Pemba. He states that some of the others came from Digu [Digo] and Zigua [both in eastern mainland Tanzania]. They were there three days making the passage, owing to the English boats. Since landing, he has worked in the plantations from which he escaped eight days ago. He hid himself in the Woods until seeing an empty canoe, he availed himself of it to come off to the ship. ${ }^{30}$

29. Charles E Gissing, HMS Osprey at Muscat to Sir Frederick W. Richards, Commander in Chief, East Indies Station (19 June 1887), enclosure: "Statements of Fugitive Slaves" HMS Osprey at Ras al Hadd. (9 June 1887). National Archives (formerly Public Records Office), London, UK (hereafter PRO) Admiralty (hereafter ADM) 1/6863 Commander in Chief - East Indies - 1887. For Shangani and Malindi, see Abdul Sheriff (ed.), The History \& Conservation of Zanzibar Stone Town (Zanzibar: The Department of Archives, Museums \& Antiquities/London: James Currey/Athens: Ohio University Press, 1995). We have not been able to locate Msena, but we assume it was near Sur, perhaps in the vicinity of Khor Jarama.

30. Commander HMS Griffon to Senior Naval Officer, East Africa (29 July 1888), enclosure: Statement of Muhandu, Slave fugitive (25 July 1888), ADM 1/6917 Commander in Chief - East Indies - 1888. For the recent development of a Bondei identity see Justin Willis, "The Makings of a Tribe: Bondei Identities and Histories," The Journal of African History 33, no. 2 (1992): 191-208. 
In these testimonies, the naval officers do more intervening than moderating in conveying the narratives, but the stories have value, even if the voices of the ones telling them are almost entirely lost in translation and moderation. We learn about the process of enslavement, elements of the passages of the enslaved, and some dimensions of slave life in various environments - even if the questions to which a slave is forced to respond almost entirely dictate the direction of the narrative.

More narratives of this sort are preserved in court records emerging from the British antislavery campaign in the Indian Ocean. Vice Admiralty courts established in the 1860s to adjudicate cases of vessels captured by British antislavery patrols close to the sites of capture preserved some of best, if shortest, testimonies of newly captured slaves. Testimony recorded by John Kirk at Zanzibar during the trials of alleged slavery cases reveals a magnitude of information in only a few words. The testimonies of a few witnesses aboard a dhow belonging to Ali bin Nasser captured by the HMS Nymphe in 1869 , for example, paint a picture of some elements of slave life in coastal East Africa.

Mubruki: I am a slave of Ali, an Arab of Mombas. I was born in Mombas in the house of Ali. My father and mother were bought. I was born a slave. I have always been in that family. I served my master as his domestic attendant, cooking and bringing water to wash his hands when he prayed. My master owned cargo in this dhow. I heard that he would buy millet seed, Indian corn or slaves if he could get them. I left Mombas in company with my master. We touched at Zanzibar, took in cargo and had not entered any port in the African Coast when we were captured.

Simba states, I am Mungalla [meanng he came from Mongalo, in southeastern Tanzania], my master is Kipae, I and Morudo Mbi are slaves of one master. I have been two years his slave at Mungao [Mongalo], and one year at Mombassa. We went to get a cargo of corn, I dare say if he came across slaves he would buy them but we went for corn.

Morndo Mbio: I am Myao [Yao, from northwestern Mozambique or southern Tanzania], I am a slave of one Bwana Kipaie, I have been a slave for one year when bought I was taken to Mombassa. From Mombassa I followed my master to Mungao, we went to buy corn beans and rice. ${ }^{31}$

31. Proceedings in the case of Dhow of Ali bin Nasser No. 15, HMS Nymphe (14 April 1869). ZNA AA 7/3 Vice Admiralty Proceedings. For the mixed Makonde and Swahili coastal town of Mungao/Mgao/ Mongalo, located to the south of Kilwa, near Lindi, in the late eighteenth century, see Alpers, Ivory and Slaves in East Central Africa (Berkeley \& Los Angeles: University of California Press, 1975), 190-191. John Kirk defined "Ngao" as "the region of Cape Delgado." ZNA, AA 7/3 Vice Admiralty Court. See also 
In a later set of cases in 1872, when the HMS Wolverine was adjudicating its slave trade cases at Zanzibar, the following testimony was recorded through an Ngindo interpreter:

Mabrook states, I am of the Ngindo tribe, have been a slave for a short time at Lamu [on the Kenya coast], ran away on account of constant bad treatment, got into a dhow going to Pemba, landed at Pemba, saw this dhow now captured at a place in Pemba, got on board and gave myself up to the people, I swam a creek to get to them, was taken on board, but they then seized me, tied me, and kept me on the way to Zanzibar, at Zanzibar they still kept me and I could not get out of their hands, when we sailed for Pemba on the return voyage they tied me again up the mast and only released me when the Man of War fired a gun to stop the dhow, I was kept by one Mabrook whom I supposed to be Captain of the dhow, he took me as his slave and tied me up. ${ }^{32}$

As this sample of testimonies demonstrates, the slave narratives preserved in British admiralty records from the Indian Ocean are brief and heavily mitigated by those who recorded them. Yet these narratives preserve a dimension of African voice and preserve valuable information for historians of Indian Ocean slavery. Rasiki's story of being kidnapped while doing laundry on the beach and Muhandu's recollections of being tricked into delivering a letter to his kidnapper help elucidate the process of enslavement in East Africa. The narratives from the HMS Osprey in Oman reveal details about the journey from Africa to Arabia and provide a window into one potential reason for the failures and inefficiencies of the British antislavery campaign in the Indian Ocean. Jusef and Rasiki recalled keeping "right out to sea" instead of hugging the coast and visiting intermediary ports for water and supplies along the journey, and they recounted disembarking several miles south of the major port city of Sur and traveling thence by foot instead of docking in the harbor at Sur. From the 1850s through the 1880s, British antislavery patrols operated on the assumptions that slaving dhows kept close to the coast of southern Arabia and that accurate surveillance of slave importations could be made from port cities. ${ }^{33}$ These narratives help scholars of Indian Ocean slavery understand how the slave trade may have persisted despite the surveillance of British cruisers and why antislavery efforts remained

John Kirk, "A Visit to the Mungao District, near Cape Delgado, Proceedings of the Royal Geographical Society of London 21, no. 6 (1976-1877): 588-589. Charles Sacleux, Dictionnaire Swahili-Français (Paris: Institut d'Ethnologie, 1939), 550, defines the Mgao as the coast between the Rufiji River delta and the Bay of Tungi, the farthest reach of the Sultan of Zanzibar, to the south of Cape Delgado.

32. No. 1 of 1872 HMS Wolverine v. Zanzibar Dhow, Seized 9 Jan. 1872, Condemned Jan. 11, 1872. ZNA AA 7/4 Proceedings Vice Admiralty Court. Judging by his name, Mabrook was himself probably enslaved.

33. See Christopher Lloyd, The Navy and the Slave Trade: The Suppression of the African Slave Trade in the Nineteenth Century (London/New York/Toronto: Longman, Green and Co., 1949), 248-257. 
so inefficient.

Following the abolition of the slave trade by Zanzibar in 1873, British naval patrols in the waters between the Mrima coast of mainland Tanzania and Zanzibar and Pemba islands frequently encountered runaways who sought protection from the British navy. ${ }^{34}$ The short passage from Mrima ports to Zanzibar and Pemba was regularly resorted to by slavers who sought to introduce small lots of enslaved Africans into the islands, ${ }^{35}$ often under the guise of their being someone's domestic, rather than new, slaves. ${ }^{36}$ For example, at the beginning of 1878, Captain G.L. Sullivan of HMS London reported "5 fugitive slaves who came off in a canoe from a place near Chake Chake in Pemba stating that their master beat them and they wanted to be free." ${ }^{37}$ Two years later Commander C.S. Hawkins wrote from Zanzibar that he was stymied by what to do with a man who claimed "That he was a slave to a fisherman living in Shangani, that his master ill-treated him and was going to sell him, he therefore ran away and the night of the $11^{\text {th }}$ January - 80 crossed over to the sand bank called Kisiki [a reef just south of Zanzibar Town] on the charts, and was across to get refuge in a Man of War, when he was picked up by a boat of this Ship," HMS Dragon. ${ }^{38}$ Somewhat differently, Kirk reported later that year on "a native of Zanzibar named Hamed Brohim who having been sold into slavery escaped from a ship in the harbour of Jeddah and was there protected by the British Consul through whose good offices he will be sent to Zanzibar." 39

A richer source dates to January 1882, when S.B. Miles sent a report to the British government regarding eight fugitive slaves from Pemba who sought refuge on board HMS Philomel..$^{40}$ Short statements were obtained from all eight individuals, so that while

34. Although the following records are located in the British consular records for Zanzibar, many can be classified as Admiralty documents because they refer to fugitives seeking refuge aboard British navy ships. According to Sacleux, Dictionnaire Swahili-Français, 591, the Mrima refers to the coast between Vanga, on the Kenyan coast at the border with Tanzania, and the Rufiji River delta.

35. See Erik Gilbert, Dhows \& the Colonial Economy of Zanzibar 1860-1970 (London: James Currey, 2004), 56-57.

36. This same ruse was used by French slavers in the Mascarene Islands after the abolition of the slave trade by Great Britain in 1810 and France in 1815 under a system known as "francisation." See Alpers, Ivory and Slaves, 214 and n.20.

37. Kirk to My Lord, 10 January 1878 enclosing Sullivan to Kirk, Sunday (date illegible), ZNA, AA1/18. For his earlier experiences in East African waters, see G.L. Sullivan, Dhow Chasing in Zanzibar Waters and on the Eastern Coast of Africa (London: Dawsons of Pall Mall, 1967 [1873]). For his service as Captain of HMS London, see Lloyd, The Navy and the Slave Trade, 251, 270.

38. Commander C.S. Hawkins to Captain Hamilton Earle, H.M. Ship Dragon, Zanzibar, 15 January 1880, ZNA AA1/27.

39. Kirk to Salisbury, 10 November 1880, ZNA, AA1/27.

40. S.B. Miles to Granville, 12 January 1882, with attached statements from the eight fugitives, ZNA, AA1/30. Miles served for 14 years as British Political Agent and Consul at Muscat and as Acting Consul-General at Zanzibar in 1882-1883 during John Kirk's leave to recuperate his health in England. See 
no one testimony is very detailed, together they provide a representative sampling of experiences of enslavement. Hassani Mbeesa ran away from his master, one Hamis bin Muhammad al Suakin, at Pemba, "because I had hard work to do." He added "I was stolen from my country when young and brought to Zanzibar with 15 others in a dhow some years ago \& sold to Nasir bin Mohammed who took me to Pemba. I have a wife at Pemba who is a slave to the daughter of Hamis bin Muhammad." Walyde Mrima stated "I was stolen from Kilwa by a man named Seringa about a month [?] and brought to Pemba. I have been there five days in the Shamba [farm] there were eleven slaves in the dhow \& we were landed near Mchumbe [possibly the coral reef island $8 \mathrm{~km}$ southwest of Zanzibar Town] \& my master's name is Hasan and I ran away when I saw the English ship." Mataka Nyassa said "I was brought from Kilwa to Pangani [on the Mrima coast] \& thence to Pemba about 2 months ago. There were 20 other slaves in the dhow that brought me \& we were landed at Chakechake. My master's name is Matari \& I ran away because I was beaten." Faraj Mbeesa "was brought to Zanzibar by Seif bin Ali about a year ago and was then taken to Pemba where I was sold to Saidi a Swahili. I was taken to Pemba by a Kilwa man named Mweza [Moya?] Mkwenda. When the ship came to Pemba we were tied up \& I was beaten because I tried to run away. Afterwards we were released on promising to remain \& I then immediately ran away off to the ship. I had been four days in Pemba when I escaped." Another Bisa captive, Mitimigi Mbeesa, "was sent to Pemba from Bagamoyo [the major central Tanzanian port at this time] by a woman \& was sold there to another woman named Bint Salima about six months ago. I had been in Bagamoyo a month, I ran away because I had work to do. I was beaten or ill treated." Another man, Juma Nyassa, recounted, "I was a slave in Zanzibar to one Hassan Ali with whom I have been three years. A month ago he sent me to Pemba to be sold \& I was purchased there by one Sherif Mussa at Mkambi [?]. I ran away because I did not like Pemba \& preferred to live in Zanzibar. My master Hassan Ali took me to Pemba himself but when he heard the soldiers were coming he returned to Zanzibar without having received my purchase money" 41

The testimonies of these eight men tell us a great deal about the experience of enslavement and slavery in East Africa. They include recent captives who were only a short remove from their natal homes, as well as those who had been enslaved for a longer period of time. One among them was actually born into slavery. All were adults. A common theme in all eight accounts is their unhappiness at being enslaved in or taken

Reginald Coupland, The Exploitation of East Africa 1856-1890: The Slave Trade and the Scramble (London: Faber and Faber, 1968 [1939]), 378, n. 2.

41. The "soldiers" to whom Juma Nyassa refers were undoubtedly members of the Sultan's armed force that was organized and commanded by Lieutenant Lloyd William Mathews of the British Royal Navy from 1875 to 1888. This armed force also received armaments and ammunition from the British Government. In December 1881, only a month before this testimony, part of this force had been instrumental in suppressing a rebellion in Pemba. See Coupland, Exploitation, 241-243, 252-253. 
to Pemba, which suggests that conditions for slaves on that island were considered to be less favorable than those on Zanzibar. ${ }^{42}$ This perspective is most vividly expressed by Juma Nyassa, whose testimony suggests that he would not have sought to escape his confinement had Hassan Ali kept him as a slave in Zanzibar. Indeed, these accounts suggest that, a decade after legal abolition of the slave trade by Zanzibar, the difficulty of replacing bonded labor may have shifted the negotiated relationship between slave owners and enslaved to the point that reasonable treatment was expected by the latter. ${ }^{43}$ It also seems evident that by 1882, a decade after abolition of the slave trade by the Sultan of Zanzibar, enslaved Africans on the two islands were well aware of the presence of the British navy in their offshore waters and the option this presence offered for those who were dissatisfied with their treatment in bondage and where the local terrain was not favorable for marronage. These accounts also are valuable in bearing witness to the ethnicity of many enslaved Africans at Zanzibar, whose surnames often derived from their "tribal" origins. They include three Bisa from northeastern Zambia, two Nyasa (read Chewa) from Malawi, one Yao from northwestern Mozambique, one man from the coast, as his surname "Mrima" indicates, and one creole, who nevertheless retained his Yao origins in his surname. In addition, we also learn something about the origins of the people who owned slaves at this time. Among the Arab owners, they included one Hadrami (Said bin Rashid El Jahadhrami), one Sudanese (Hamis bin Muhammad el Suakin), two Ashräf (descendants of the Prophet), several Swahili, and two women. Although each of these testimonies contains similar information about the circumstances of enslavement and the reasons for seeking refuge with the British navy, there is no evidence that there existed a script which governed the interrogations that yielded these responses. Nevertheless, the fact remains for these, as for all of these official encounters, some unknown person - the translator - stood between the individual whose story was being memorialized and those British officers who recorded it.

In at least one case of which we are aware it is clear that a set of guidelines or set of questions did exist and that it accordingly shaped the information that has come down to us. On 13 January 1880 the commandant of the French island colony of Mayotte, in the Comoro Islands, assisted by an interpreter named Amadi Sabaoma, interviewed a group of six children who had been brought as engagés - so-called free laborers - to work on three different French sugar plantations. ${ }^{44}$ According to one of the children named Ktéa,

42. Frederick Cooper, Plantation Slavery on the East Coast of Africa (New Haven and London: Yale University Press, 1977), 167-168.

43. See ibid. and Jonathon Glassman, Feasts and Riot: Revelry, Rebellion, and Popular Consciousness on the Swahili Coast, 1856-1888 (Portsmouth, NH: Heinemann, 1995). Also see Martin Klein, Slavery and Colonial Rule in French West Africa (Cambridge: Cambridge University Press, 1998), 13-15.

44. This document, "Enfants <<engagés>> venus de Mozambique et de la Grande Comore, interrogés à Mayotte," is published in Klara Boyer-Rossol, "De Morima à Morondava: Contribution à l'études Makoa de l'Ouest de Madagascar au XIX siècle," in Didier Nativel and Faranirana V. Rajaonah (eds.), Madagas- 
Amadi Sabaoma was identified as being "a recruiter for the Compagnie des Comores with whom I stayed from the time of my arrival at Grande Comore last September," i.e. three months previously. ${ }^{45}$ Each interrogation began with the Commandant asking the child his or her name, then where they came from, followed by questions about their parents, the circumstances of their becoming engagé, and, finally, whether they would like to return to their home. Four of the children had been assigned slave names, although three of them remembered their original names. All six children came originally from Mozambique, but were apparently transported directly to Ngazidja (Grande Comore) before being sent to Mayotte. In response to the question of how they came to leave their parents, four indicated that they were sold by their relatives, one said he was stolen from his parents, and one stated that he was captured in war. Several identified the person responsible for bringing them to the Comoros, while others noted that they were brought for labor on Mayotte by Amadi Sabaoma. Finally, none of the children indicated that they wanted to return either to Mozambique or to Ngazidja, most stating that they were unhappy at home, while one noted that his mother was dead and Ktéa said that he was unhappy because he had noting to eat at home. This response is not surprising, since most had been sold into slavery by relatives. However, the fact that these interviews were conducted by an interpreter who was the same individual who had recruited them to work on the sugar plantations in Mayotte in what was probably the Ngazidja dialect of Comorian, a language that they would only have begun to acquire recently, and French, a language that they surely did not understand, raises important questions about the accuracy of their evidence.

\section{Consular records from East Africa}

Consular records from East Africa, comprise our second category of sources. The first example of this set of sources reflects the diligence of the committed abolitionist Colonel Christopher Palmer Rigby, who was British Consul at Zanzibar and Muscat from July 1858 to September 1861. From February to September 1860 Rigby made his own short but detailed notes on depositions taken at the British Consular Court from 13 enslaved

car et l'Afrique: Entre identité insulaire et appartenances historiques (Paris: Éditions Karthala, 2007), 183217 at 211-214. Ned Alpers is grateful to Ms. Boyer-Rossol for sharing this document with him before publication and to Philippe Beaujard for sending him a copy of this book. The problem of engagés also endured at the French colony of La Réunion into the late nineteenth century. See Yvan Combeau, Prosper Eve, Sudel Fuma, and Edmond Maestri, Histoire de La Réunion: De la colonie à la région (Université de La Réunion, CRESOI and Éditions SEDES, 2001), 77-82.

45. For plantation capitalism in the Comoros, see Malyn Newitt, The Comoro Islands: Struggle Against Dependency in the Indian Ocean (Boulder: Westview Press/London: Gower, 1984), 97-98. For the Compagnie des Comores and problems of labor recruitment at Mayotte, see Martin, Comores, vol. 2, 184-186, 196-204; Guy Fontaine, Mayotte (Paris: Éditions Karthala, 1995), 17-18. 
Africans who were held illegally by British Indian subjects in Zanzibar. ${ }^{46}$ Seven of the Africans interviewed were males between the ages of 8 and 24 and six were females ranging from age 6 to 22. Their depositions merit full presentation because of the details they reveal about how slaves were acquired and some of the conditions of labor on Zanzibar.

According to Nasiboo, a male, about 18, "of the Myiao [Yao] tribe": "About four months ago I was seized by Africans of another tribe, whilst working near my own village." He continued:

I was taken to Keelwa with forty other slaves, we were one month on the journey; at Keelwa I was purchased by an Arab, I was then put on board a Dow with forty or fifty other slaves and brought to Zanzibar. On arriving at Zanzibar I was taken to the home of the Arab who had purchased me at Keelwa. I was kept ten days in his home, and fed upon sweet potatoes, I was not taken to the slave market at Zanzibar, my present Master Kanoo the Banian came to the house of the Arab and purchased me, and took me direct to his plantation in the country. I don't know what the Banian paid for me. I have worked for the Banian ever since he purchased me nearly three months ago, he has never given me any money. $\mathrm{He}$ gives me every day some Mohogo (cassava) to eat, but I never get enough to satisfy my hunger. When my Master purchased me he also purchased from the same Arab another slave by name of 'Suedi.' If I am released from slavery I can work and get my own living, and procure good food and clothes. ${ }^{47}$

This same Suedi "of the Myiao tribe," who was about 17 years of age, confirmed the account provided by Nasiboo.

About six months ago my tribe was at war with another tribe; I was taken prisoner and conveyed to the Port of Keelwa. I was two months on the journey; at Keelwa I was sold to an Arab who conveyed me in a Buggalow ${ }^{48}$ to Zanzibar, on arriving

46. With exception of Goans, who were Portuguese subjects, all Indians in Zanzibar were considered to be British subjects and were consequently forbidden to own slaves. See Robert G. Gregory, South Asians in East Africa: An economic and social history, 1890-1980 (Boulder, CO: Westview Press, 1993); Abdul Sheriff, Slaves, Spices \& Ivory in Zanzibar: Integration of an East African Commercial Empire into the World Economy, 1770-1873 (London: James Currey, 1987), 202-208.

47. Rigby's notes, British Consular Court, Zanzibar, 5 February 1860. Depositions of various African slaves belonging to Kanoo Mungee, Banian, British subject residing at Zanzibar, ZNA, AA3/11. Kanoo Mungee also owned another 62 slaves whom Rigby liberated and for whom he recorded ethnic origins. Rigby's notes are written upside down on the blank pages at the back of a register of letters ending at 1855. For more details of Rigby's actions with respect to Kanoo, see C.E.B. Russell, General Rigby, Zanzibar and the Slave Trade (London: Allen and Unwin, 1935), 86-87, 140, 142.

48. Probably a variation of a baggala, "the traditional deep-sea dhow of the Persian Gulf and the Gulf of 
at Zanzibar I remained ten days in the house of the Arab, whose name is 'Bana Abdallah'. I was not taken to the slave market for sale, my Master Kanoo Banian purchased me from Bana Abdallah, and took me at once to his plantation in the country. ${ }^{49}$

The story told by Khamsini, the oldest Yao at 24, reveals that although the circumstances of his initial capture were similar to Suedi's, those of his sale to Kanoo Mungee were different:

About three years ago my tribe was attacked by another tribe and I was taken prisoner. I was taken a journey of two months to Mungao on the sea Coast and was there sold to an Arab by name 'Masood' and I was with him two years. About nine or ten months ago my present master Kanoo Banian came to Mungao and purchased me of my late Master. A few days after Kanoo bought me he shipped me in a Dow and brought me to Zanzibar. Besides myself Kanoo brought seven slaves with him from Mungao to Zanzibar, of these three were females, and two, young boys, of whom one is since dead. Since I have been at Zanzibar I have worked in the town for my Master, conveying goods to and from the Custom House, \&c." ${ }^{50}$

Like Nasiboo, another young Yao male, Mazariwa, ${ }^{51}$ aged 18, was also kidnapped, ending up being purchased at Mungao with Khamsini:

About two years ago I was in a field of Indian corn [maize] near my own village when I was seized by some men of another tribe, and was kept as a slave for nearly a year amongst the Makondi [Makonde, in southeastern Tanzania and northeastern Mozambique] tribe. I was then taken a journey of a month and a half to Mungao on the Sea Coast, I was there four days and was then purchased by my present Master Kanoo the Banian, he paid some cloth for me. Kanoo then shipped me in a boat with seven other slaves and brought us to Zanzibar. I came to Zanzibar about nine or ten months ago and have since worked in the town for

Oman. Its distinguishing features are the five-windowed stern, which is often elaboprately carved in the manner of an ancient Portuguese caravel." Alan Villiers, Sons of Sinbad (New York: Charles Scribner's Sons, 1940), 417.

49. Rigby's notes, British Consular Court, Zanzibar, 5 February 1860. Depositions of various African slaves belonging to Kanoo Mungee, Banian, British subject residing at Zanzibar, ZNA, AA3/11. 50. Ibid.

51. This man's name appears to be derived from Swahili mzalia, meaning a locally born slave or someone of slave descent. 


$$
\text { my Master. }{ }^{52}
$$

The youngest male in this group, named Mubrook [Mabruk, ironically meaning "blessed" or "congratulations!"], a common Muslim slave name, and "of the tribe Makondeh" was only 8 years old. He testified: "I don't remember how I was seized or who took me to the shore." Kanoo Mungee bought him at Mungao and brought him to Zanzibar about ten months previously and he worked on Kanoo's plantation at the time of his deposition.

The two women whose accounts Rigby wrote down in detail were Shereefah, age 20, and Hidayah, 22, both Myassa tribe "(on the borders of the great Lake Nyassa)" according to Rigby's notes. Shereefah's reported answers in a series of short, parallel sentences suggest strongly that she was responding to set of questions from the bench:

I was taken prisoner many years ago by some people of the Makondeh tribe. I lived with them until two years ago when I was taken to Mungao on the Sea Coast and then sold to a Banian. I lived with this Banian until his death which occurred about a year ago, when my present Master Kanoo Banian came to Mungao and purchased me and brought me to Zanzibar with seven other slaves, of whom two were boys and three were females. My Master had purchased twenty slaves at Mungao and twelve of these ran away before shipment.

She claimed never to have been paid, or to have received more than a little food and clothing; if free, she said she could work "and procure decent clothing." 53

In her deposition, Hidayah similarly provided the following details of her enslavement and experiences in bondage:

I was seized and taken from my own country when I was very young and therefore I do not remember the circumstances. I was for some years held in slavery at Mungao by an Arab by name 'Syed bin Toomah'; about two years ago my Master sent me to Zanzibar to be sold. I was sold by auction in the slave Market and my present Master Kanoo purchased me; I have since lived in his home and worked for him. I have never received any money from him, he gives me neither food nor clothing, but sends me out to work and earn money for my own support. ${ }^{54}$

Within the estate of this one Hindu slave owner we can see a broad spectrum of

52. Rigby's notes, British Consular Court, Zanzibar, 5 February 1860. Depositions of various African slaves belonging to Kanoo Mungee, Banian, British subject residing at Zanzibar, ZNA, AA3/11.

53. Ibid.

54. Ibid. 
experiences of the enslaved, some of whom were captured in war or raiding, some who were kidnapped, and some who were apparently enslaved as very young children. In the 1850s French naval captain Charles Guillain reported that sales of slaves at Kilwa Kivinje were negotiated individually with local merchants, a pattern that conforms to these accounts and one which Kirk confirmed in 1873 when he observed that slaves were kept for illegal sale in the compounds of individual slave dealers. ${ }^{55}$ Similarly, the accounts recorded by Rigby appear to reflect the same pattern of purchases at Mgao. We can also see that many of the enslaved spent a considerable amount of time as slaves either to other Africans or to coastal slave owners ("Arabs") on the continent before ever being transported overseas. ${ }^{56}$ Kanoo Mungee acquired two of them by buying them from another slave owner at Zanzibar, one was purchased at auction in Zanzibar's notorious slave market, and the other five in a larger purchase directly at the coast. Some of these individuals worked on his plantation, but others worked for him in town or in his home. ${ }^{57}$ Finally, it seems evident that Kanoo Mungee did not provide much in the way of food or clothing for his slaves and that he was distinctly unpopular with these individuals who testified against him.

In July, Rigby recorded the testimony of another 16-year-old young woman who was also named Hidayeh and whose testimony bears further witness to the operation of the slave trade in eastern Africa.

I belong to the tribe of Uniamesi [Unyamwezi, in western Tanzania], my native country is on the West (sic) shore of the Lake of Ujiji; about fourteen months ago I was seized by people of another village and sold to some Arabs. The Arabs brought me to Bagamoyo on the Sea Coast. I arrived at Bagamoyo about seven months ago, and on arriving there I was purchased by the prisoner Hurjee [bin Nassur, a Khoja] from the Arabs. Many slaves were brought down to the Coast with me, most of them were brought to Zanzibar for sale. I don't know what the prisoner paid for me. We received sufficient food, it consisted of Jowaree [sorghum bicolor]. ${ }^{58}$

Finally, in September Rigby took detailed notes on the case of Ragoojee Namia, age 33, a Banian who was charged with a recent illegal purchase of slaves in violation of

55. David Lawrence Horne, "Mode of Production in the Social and Economic History of Kilwa to 1884," Ph.D. dissertation, University of California, Los Angeles, 1984, 190-194, 159.

56. See Morton, "Small Change" and Alpers, "The Other Middle Passage."

57. For the different types of work performed by enslaved Africans at Zanzibar, see Cooper, Plantation Slavery, 153-200, 211-212.

58. Rigby, British Consular Court, Zanzibar, 24 July 1860, ZNA, AA3/11. 
Rigby's explicit order warning against such slaving by British subjects. ${ }^{59}$ The accounts by the five young Africans who were deposed in this case speak to the recent ravages of the terrible cholera epidemic that swept through East Africa in 1859 and the hazards of kidnapping and untrustworthy relatives. ${ }^{60}$ As an 18 -year-old Yao man named Toombo declared:

I was seized by my own elder brother and taken to Quali [Kwale] on the sea Coast and sold by my brother to my present master the prisoner before the court. I do not know what he paid for me. When I say that my own elder brother sold me I mean that he was my half brother by the same father but different mothers. My mother was also sold with me by my half brother. The reason he sold us was because there was a famine in our country and we could not procure any food. My mother died about nine months ago, just after we arrived at Quali, where the prisoner my master resides. ${ }^{61}$

All five individuals ended up on the far northern Mrima coast, where the defendant purchased and kept them in his house at Kwale until he decided to bring them over to Zanzibar. Several of the witnesses stated that they were purchased with cloth, rather than money. In addition to the Yao Toomba, there was one other Yao (a 6-year-old girl named Fikri), two Magangeh [Mang'anja] or southern Cewa (the 14-year-old Baraka and a girl named Faidah, who was 9), and an Ngindo young woman of 14 named Majooma.

Each of these testimonies reveals valuable information about elements of the process of enslavement, the journey taken by the enslaved, and some dimensions of slave life in East Africa. Yet these testimonies beg some obvious questions, namely how they came to be written down and how clearly the voices of interviewees have been conveyed through the process of interrogation and translation. Since most of these testimonies were recorded in conjunction with either court cases or manumission records, they appear mostly to include the direct responses to interview questions. Behind each "I don't know what he paid for me," we can imagine a very direct question about price. Such questions might tend to lead a witness to provide only the information sought by the interrogator, stifling

59. The Vanìya are a Gujarati Hindu trading caste. For a valuable explication of the term, see Pedro Machado, Ocean of Trade: South Asian Merchants, Africa and the Indian Ocean, c. 1750-1850 (Cambridge: Cambridge University Press, 2014).

60. For the devastation caused by the introduction of cholera from India in the nineteenth century, see Juhani Koponen, People and Production in Late Precolonial Tanzania: History and Structures (Helsinki: Finnish Society for Development Studies, Finish Anthropological Society, Finnish Historical Society, Scandanavian Institute of African Studies, 1988), 159-162.

61. Rigby, British Consular Court, Zanzibar, 4 September 1860, ZNA, AA3/11. Because Yao society was matrilineal, Toombo's patrilaterally-linked brother would have had no direct kinship connection either to him or to Toombo's mother. 
the voice of the enslaved. However, these exchanges are valuable not only for the details which enslaved Africans managed to supply, but also for the window they provide into the minds of the individuals involved in the actual implementation of British antislavery policy in the Indian Ocean. Rigby appears to have been very curious about the prices paid for slaves in East Africa and the routes by which they were brought to Zanzibar, but he seems less interested in the precise names and locations of slave dealers and previous masters, which perhaps reflected a sense of hopelessness of fully enforcing abolitionist policy. He appears even less concerned about the root causes of enslavement in terms of the commodities these slaves were employed to produce and the environmental and social conditions which led to their enslavement.

\section{Consular records from Arabia}

The third and final category of official sources involves similar histories taken from fugitive enslaved Africans who were liberated or sought manumission at British consulates in Arabia. A report from 1857 provides short statements by nine men and eight women, ranging between 9 and 60 years of age, who had been sent as slaves to Zanzibar, where many of them were subsequently kidnapped and shipped to Arabia before being liberated at Muscat and transported to Bombay aboard the British merchant ship "Coeur de Lion." ${ }^{2}$ With the exception of one woman who had three children and wanted to return to Zanzibar, all of them wished to remain in Bombay alleging that "being slaves in their country they have no wish to go back." These accounts give less information than do the other testimonies about the character of each individual's initial enslavement (although kidnapping would seem to be a common thread in their statements), and concentrate on the kidnappings that occurred after each had been settled with a slave owner at Zanzibar. According to Abdulla, a Yao man aged about 24 who had lived for 15 years at Zanzibar "in the service of one Salmeen ... about six months ago [he] was captured by a large body of men of the Sooree caste [sic], while out, pinioned, conveyed to Zanzibar [Town?], and thence shipped to Muscat." The same happened to a 40-year-old man named Nimbamza who had been enslaved at Zanzibar for about two years "in the service of Abdool Vayman," and who was apparently snatched by the same group of Suris headed by one "Mahomed" that abducted Abdulla. Damassee, aged about 22, was born into slavery at Zanzibar and had lived with a man named Hanamdee "till about 2 or 3 months ago when he was taken by one Abdoola and a number of men of Sooree caste" and shipped off to Muscat. Several of the females who were liberated at Bombay emphasized that they were seized while away from the security of their households, in several cases when they were carrying

62. For details on the "Coeur de Lion," see the exchange on Mariners-L Archives at http://archiver.rootsweb.com/th/read/Mariners/2005-08/1124700720, accessed on 18 December 2007. 
messages for their masters, in others while they were out gathering wood or food. ${ }^{63}$

Several valuable details emerge from these 17 statements. First, they express a general sense of the constant threat of being snatched up and spirited away from Zanzibar at any moment, even for enslaved Africans who had resided at Zanzibar in a stable relationship as bondspersons for many years. Second, there is little doubt that the main players in this kind of kidnapping, which upset the stability of the slave regime at Zanzibar, were Suri Arabs from Oman, Sur being the center of the slave trade in the Arabian Gulf. ${ }^{64}$ Third, we find curious the Anglo-Indian habit of referring to all Africans as "Seedees" in rendering these statements, as if there were no distinctions that needed to be made among Africans by their ethnicity. ${ }^{65}$

Some of the best sources of information about the lives of enslaved Africans in the Gulf come from the testimonies which they provided a half century and more later when seeking manumission from British officials at Gulf consulates and agencies at Bahrain, Sharjah, and Muscat. Although British policy generally tended to tolerate the institution of slavery in Eastern Arabia, the Gulf administration was loath to tolerate cases of physical abuse and blatant neglect within its jurisdiction. ${ }^{66}$ It thus maintained a policy, which became systematic after 1921, of granting official manumission certificates to runaway slaves who were victims of abuse. Embossed with an official government seal and rendered in both English and Arabic, government manumission certificates were highly valued among manumitted slaves as one means to secure a degree of freedom and respectability in Gulf society. In order to receive a manumission certificate, slaves were required to present themselves at British consulates or agencies and testify as to their identity and condition. The manumission testimonies reveal significant aspects of life among enslaved Africans in the Gulf in the late nineteenth and early twentieth centuries and allow some general conclusions to be drawn about the nature and process of enslavement. Furthermore, by working backward from the loose dates provided by slaves in their testimonies, historians today can gain perspective on the duration and extent of the slave trade in certain periods.

A statement given in Muscat in 1930 by Walaid bin Mulla, a 40-year-old enslaved pearl diver, provides details about the way in which he was enslaved, the route that brought him to Arabia, and details about his work and treatment in the Gulf. Walaid's statement reads as follows:

63. C. Forjett to Crawford, Bombay, 27 November 1857, ZNA, AA3/17.

64. For Suri Arabs, see Matthew Scott Hopper, "The African Presence in Arabia: Slavery, the World Economy, and the African Diaspora in Eastern Arabia, 1840-1940," UCLA Ph.D. dissertation, 2006, 43. 65. See Amy Catlin-Jairazbhoy and Edward A. Alpers (eds.), Sidis and Scholars: Essays on African Indians (Noida, U.P.: Rainbow Publishers, 2004).

66. Hopper, "Imperialism and the Dilemma of Slavery in Eastern Arabia and the Gulf, 1873-1939," Itinerario 30, no. 3 (2006), 76-94. 
My native place is Yukamba [Ukambani, in eastern Kenya]. When I was about 15 years old I went to Mombasa in order to work there and while I was going one day to the gardens to bring coconuts a certain Muhamad of Sur met me on the way and kidnapped me and took me to his boat which sailed immediately from Mombasa for Sur where he sold me to a man named Khamis. After 10 days Khamis took me by boat to Ras Al Khaimah where he sold me to Ali bin Khalifah of Hirah. ${ }^{67}$ I stayed 15 years with Ali bin Khalifah during which period I worked for him 5 years as puller and 10 years as diver. Ali bin Khalifah then sold me at Dubai to Ahmed bin Bashir who handed me to his cousin Abdullah bin Yusuf. The latter used to send me in summer to diving banks and at the termination of the diving season he was taking all my earnings. In winter I had to serve my master and to work for my livelihood as he was neither giving me any food nor clothing. I could not get any chance to escape from my master until 20 days ago when I embarked a Badan of Batinah which took me to a place near Khaburah [on the Batinah coast]. I walked from that place to Sib [Seeb, west of Muscat] and then embarked a Badan which brought me to Matrah [immediately next to Muscat]. I have now come to take refuge at this consulate and beg HBM's government to grant me a manumission certificate so that no one may be able interfere with my liberty. ${ }^{68}$

From Walaid's testimony we learn not only of his kidnapping and his journey to Arabia, but the names of his masters, the specific places he was disembarked, and several intriguing details about his life in the Gulf. Because Walaid recalled the approximate age at which he was captured (15) and we know his approximate age at the time he provided his testimony (40) in 1930, we can roughly date his kidnapping to 1905, significantly later than conventional accounts would allow for the persistence of the slave trade from East Africa to Arabia.

The testimonies of enslaved Africans who sought manumission certificates from the British government at its consulates and agencies at Bahrain, Sharjah and Muscat between 1921 and 1943 indicate that a significant slave trade persisted well beyond the abolition of slavery in Zanzibar and the termination of the British antislavery squadron in the Indian Ocean. A survey of 90 manumission testimonies given by enslaved Africans who specifically recalled being kidnapped from Africa (the same records include additional testimonies from muwālid slaves-born in Arabia-in addition to free Arabs of African

67. Ras Al-Khaimah is located in the United Arab Emirates on the western side of the far northwest peninsula of Oman at the Strait of Hormuz. Hirah is within Dubai.

68. Statement made by Walaid bin Mulla, age about 40 years. Recorded on 29th November 1930. British Library, London, UK. India Office Records (hereafter IOR), R/15/1/217 Manumission of Slaves at Muscat, 1929-1932. 
descent who were kidnapped from other parts of Arabia and enslaved, as well as Baluchi slaves) demonstrates that $62(69 \%)$ recalled being kidnapped from Zanzibar and the Swahili Coast (East Africa) and 28 (31\%) recalled being kidnapped from Northeast Africa (Ethiopia and Sudan in particular) between the years 1872 and 1927. While this sample size is too small to make any sweeping generalizations about the dates of importations of all Africans to the Gulf, it does provide evidence that the slave trade continued into the twentieth century. Of the 62 Africans who recalled being kidnapped from East Africa, more than half (32) were kidnapped between 1895 and 1910. About half of the Africans who recalled being kidnapped from Northeast Africa (15 out of 28) were kidnapped from Africa between 1900 and 1919. Using these limited figures as a rough guide, it may be supposed that some form of slave trade between East Africa and the Gulf persisted into the twentieth century and perhaps grew stronger after 1885, especially between 1895 and 1910. Not surprisingly, these dates correspond with the peak of Gulf pearl production. ${ }^{69}$ Another enslaved diver, a man named Faraj approximately 40 years of age, provided the following testimony at Muscat in 1931.

I belong to Makwa tribe who are living at Uganda [presumably Makua living at Ungindo]. When I was a child I was kidnapped by my own tribe and sold to the people of Soor who embarked me on a boat which was anchoring at Bukin [Bukini, northwestern Madagascar]. I was brought to Soor where I stayed 10 days and then sold to Muhamad bin Sulaiman of Khaburah. The latter took me first to his place Khaburah and then to Dubai where he sold me to Abduallah bin Huraiz al Bu Felasah of Dairah (Dubai). My master Abdullah sent me for fishing for about 3 years after which he handed me to one of the diving Nakhudas. My master was taking all my earnings. After 15 years my master Abdullah died. His son Muhamad took possession of me. He was also sending me to pearl fisheries and was taking all my earnings. He was neither supplying me with sufficient food and clothing nor giving me money out of my earnings for my expenses. In winter I used to go for fishing and out of the little money which I was earning, I was preparing clothes for myself. As my master was not treating me in a proper manner I ran away at night time about 8 days ago from him and embarked a boat belonging to Henjam. On arrival at [Jezirat] Henjam [a small island on the Arabian Sea side of Hormuz Island] I took refuge at the Telegraph Office. The Clerk in Charge sent me on board the mail steamer. On arrival at Bandar Abbas I intended to land there but I was not allowed to do so. I came to Muscat. ${ }^{70}$

69. Hopper, “The African Presence in Arabia," 162-218.

70. Statement made by Faraj (father's name unknown) aged about 40 years. Recorded on the 3rd February 1931. IOR R/15/1/217 (Manumission of Slaves at Muscat, 1929-1932). 
On account of the strenuous nature of their work, pearl divers accounted for a large portion of the enslaved population who sought manumission at British agencies. But testimonies of those involved in other forms of work survive as well. Sanqur bin Abdul Khair, a 40-year-old Swahili slave provided the following testimony at Muscat in 1931.

I was born in Makamayo [?], Swahil. About 20 years ago a certain man called Abdullah bin Muhammad bin Mubarak of Sur kidnapped me and took me to Braimi where he sold me to Shaikh Sultan bin Muhammad Al Naimi of Buraimi. ${ }^{71}$ The latter used to send me to the forest and I was to cut wood from there and carry it to the town where charcoal was to be made for sale. I was well treated by him. When my master died about 8 years ago, I was transferred as an inheritance of the estate to his son Abdullah bin Shaikh Sultan Al Naimi. The latter was ill treating me. He never provided me with sufficient food and clothes. If I ever happened to ask him for a little money which is earned by me and taken by him, he used to beat me severely. Thereupon I seized the opportunity and ran away from Braimi. $^{72}$

While the manumission testimonies can be a valuable source for historians interested in the lives of the enslaved in the Gulf insofar as they reveal details of enslavement and slave life, they must also be treated with a degree of caution. It would be an error to regard these testimonies as representative of the entire enslaved population of the Gulf because numerous factors have limited the number of testimonies that were recorded. For a variety of reasons, enslaved Africans who sought manumission certificates were overwhelmingly male. Additionally, many of the recorded testimonies came from the British Residency Agent at Sharjah. The agent, a man of Persian ancestry, appears to have tended to treat enslaved Baluchis (from Baluchistan or Persian Makran) graciously, but was known to have returned a great many of the enslaved Africans who appealed to him back to their masters in exchange for bribes or to bolster his tenuous position as British agent on the coast. ${ }^{73}$ As a result, most manumission testimonies from Africans enslaved on the Trucial Coast come from those who were able to escape and walk to Muscat or sail to Bahrain to appeal for manumission. The format of manumission testimonies also varied over time. British agents did not always ask those who appealed to them for manumission for details about their arrival in Arabia, and that information has not always been recorded. In some cases, testimonies of Africans who were kidnapped are missing too much information to

71. Buraimi, also known as Al-'Ain, is a major oasis on the Oman-U.A.E. frontier and was one of the last major centers for slavery in eastern Arabia.

72. Statement made by Sanqur bin Abdul Khair Swahili aged about 40 years. Recorded on the 22nd June 1931. IOR R/15/1/217 (Manumission of Slaves at Muscat, 1929-1932).

73. Hopper, "Imperialism and the Dilemma of Slavery." 
be useful in calculating back the dates of their capture. Furthermore, not all manumission testimonies have been preserved. Despite these limitations, the manumission testimonies provide significant details which help us better understand the nature and extent of slavery in this part of the Indian Ocean.

\section{CONCLUSION: ON TRANSLATION AND SPEAKING FOR THEMSELVES}

To conclude, let us return to the questions with which we began this paper. The three men who were seized by the British man o' war from the American ship "Lacouie" were apparently not understood correctly by their British liberators because the interpreter spoke only Swahili and not Makua. This single incident demonstrates vividly how significant for the historian is the question of language ability on the part of both those who were asked for their testimonies and those served as their translators. With few exceptions, enslaved Africans did not grow up speaking the languages of the Indian Ocean slave owners into whose possession they passed, whether that language was Swahili, Comorian, Arabic, French, Portuguese or Kreol. ${ }^{74}$ In addition, we usually do not know who, exactly, acted as the translator between European interrogators and their African subjects. Furthermore, the little we do know about individual interpreters raises another set of questions that could affect the accuracy of translation. Thus, as we have seen, the possibly compromised role of Amadi Sabaoma as both labor recruiter and translator for the French Commandant of Mayotte highlights how his dual role may have affected the way in which he chose to interpret the interest in returning home of the children whom he had recruited as laborers. His situation is reminiscent of another case of which we know where the interests of an interpreter, a Comorian named Lumma whose father was a chief and who was married to a niece of the ruler of Angoche, the principal slave trading port outside of Portuguese control in Mozambique, similarly may have been compromised by his position as both an employee of the Sultan of Zanzibar and an official member of the crew of HMS Gorgon who received prize money for each cargo of liberated slaves. ${ }^{75}$ In Colonel Rigby, however, whose careful notes on Admiralty Court proceedings at Zanzibar provide us with some of our best evidence, we encounter a British officer who clearly had the linguistic facility

\footnotetext{
74. For a striking example of this phenomenon, see Megan Vaughan, "Reported Speech and Other Kinds of Testimony," in Luise White, Stephan F. Miescher, and David William Cohen (eds.), African Words, African Voices: Critical Practices in Oral History (Bloomington and Indianapolis: Indiana University Press, 2001), 53-77. Alpers discusses the question of language acquisition by enslaved Africans in Ehud R. Toledano (ed.), African Communities in Asia and the Mediterranean: Identities between Integration and Conflict (Trenton: Africa World Press, 2012), 65-81.

75. W. Cope Devereux, A Cruise in the "Gorgon;" or, Eighteen Months on HMS "Gorgon," engaged in the Suppression of the Slave Trade on the East Coast of Africa (London: Bell and Daldy, 1869), 370-371. Devereux calls Lumma the ship's "informant," by which we take to include the responsibilities of being their interpreter.
} 
to understand for himself the testimony of the Africans whose words he recorded. Rigby's obituary praised him as "an Oriental linguist whom few could excel, having passed in Hindostani, Mahratta, Canarese, Guzerati, Persian, and Arabic," adding that "wherever Rigby travelled, whether in Europe, Asia, or Africa, he always studied languages with an instructor." ${ }^{76}$ Indeed, this proved also to be the case in Zanzibar where, according to his daughter, "Within a few months of landing in Africa, Rigby had acquired sufficient of the Kisowahili or coast language talked by the native population to be able to converse with slaves without an interpreter."77 Nor was Rigby an isolated case. John Kirk's Swahili was good and R.L. Playfair, British representative at Zanzibar in the mid-1860s, had workable Arabic. There is even some correspondence in the Admiralty files which indicates that some officers aboard Her Majesty's ships had passed examinations and were certified in certain Oriental languages ${ }^{78}$ Nevertheless, with the exception of skilled students of language like Rigby, we need to be cautious about how much stock we place in the accuracy of such translations of African voices during the era of the slave trade.

Finally, all of the sources we discuss in this paper were deeply affected by the spirit and legal framework of the British abolition movement. Certainly, the moral outrage and abhorrence of the slave trade and slavery that many of these European interlocutors felt influenced the way in which they understood the statements that they took from the victims of the slave trade, but we cannot summarily gainsay the veracity of such reports. ${ }^{79}$ Even if certain phrases and sentiments may reflect the attitudes of these Europeans rather than those of the liberated Africans, in the end, these are the sources we have at our disposal and as historians it is our business to make the best sense of them that we can. Above all, whatever their inherent flaws, this mixed bag of sources gives us our best insights into the lived experience of these African men, women and children, who represent the hundreds of thousands of individuals who fell victim to the greed and inhumanity of African, Arab, and Euro-American slavers in nineteenth-century eastern Africa.

76. "Obituary: Major-General Christopher Palmer Rigby," Proceedings of the Royal Geographical Society and Monthly Record of Geography, New Monthly Series, Vol. 7, No. 6. (Jun., 1885), pp. 388-390.

77. Russell, General Rigby, 139.

78. See Letter to Admiralty Board, 13 January 1874, asking for a pay raise for one Navigating Lieutenant Nankivell of HMS Daphne who has passed an examination in Swahili., ADM 1/6301/SA.31.

79. See also Alpers, "Representations." 